\title{
Extraction and Characterization of Biosilica from Raphia Africana Fruit Shells and Borassus aethiopum Leaves
}

\author{
Esther Nguumbur Iornumbe*, Orseer Sarwuan, Raymond Ahulle Wuana \\ Department of Chemistry, Joseph Sarwuan Tarka University, Makurdi, Nigeria \\ Email address: \\ estnguior@gmail.com (E. N. Iornumbe), sarwuanorseer918@gmail.com (O. Sarwuan), raynewton73@gmail.com (R. A. Wuana) \\ ${ }^{*}$ Corresponding author
}

\section{To cite this article:}

Esther Nguumbur Iornumbe, Orseer Sarwuan, Raymond Ahulle Wuana. Extraction and Characterization of Biosilica from Raphia Africana Fruit Shells and Borassus aethiopum Leaves. American Journal of Applied Chemistry. Vol. 9, No. 5, 2021, pp. 138-144.

doi: 10.11648/j.ajac.20210905.13

Received: August 15, 2021; Accepted: September 1, 2021; Published: September 23, 2021

\begin{abstract}
Agricultural wastes which include leaves, shells, husk, stalks, bagasse and ash of plants are often residues of processing or growing of raw agricultural products [1]. These wastes may contain materials that are beneficial to man despite their contribution to environmental pollution. Increase in human population has led to increase in agricultural expansion with exponential increase in waste generation [2]. Converting these wastes to useful forms is of great significance. In this study, biosilica was extracted from the ash of Borassus aethiopum leaves (BALA) and Raphia africana fruit shells (RASA) using precipitation method. The ashes obtained were characterized using Atomic Absorption Spectrophotometry (AAS). Scanning Electron Microscope (SEM), Fourier Transform Infrared Spectroscopy (FTIR) and X-Ray Fluorescence (XRF) were used to characterize the extracted silica. Morphology of the extracted biosilica using SEM revealed fine globules of various sizes formed from aggregates of biosilica at different magnifications: 150x, 500x and 1000x. FTIR spectra of the extracted biosilica revealed the presence of hydroxyl $(\mathrm{OH})$, silanol $(\mathrm{Si}-\mathrm{O}-\mathrm{H})$ and siloxane ( $\mathrm{Si}-\mathrm{O}-\mathrm{Si})$ functional groups recorded at absorption bands: $3395.6,1636.3$ and $1062.3 \mathrm{~cm}^{-1}$ respectively for BALA and $3388.2,1640.0$ and $1058.6 \mathrm{~cm}^{-1}$ respectively for RASA. $\mathrm{XRF}$ of the extracted biosilica showed two major peaks which correspond to the presence of silicon and oxygen atoms respectively. Percentage extraction of biosilica from the two precursors was between 70-90\%. AAS result revealed that BALA had biosilica $67 \%$ while RASA showed $82 \%$ biosilica content. This study revealed that the leaves of BALA and fruit shells of RASA are good sources of silica and as such, converting waste to wealth thereby reducing green-house gases like $\mathrm{CO}_{2}$ released into the atmosphere when left to decompose naturally.
\end{abstract}

Keywords: Biosilica, Borassus aethiopum, Leaves, Raphia Africana, Fruit Shells, Ash, Extraction, Characterization

\section{Introduction}

One of the basic materials and valuable inorganic multipurpose chemical compound is silicon dioxide $\left(\mathrm{SiO}_{2}\right)$ commonly known as silica. It is known to occur in nature as sand, quartz or flint and exists as gel, crystalline and amorphous forms [3]. It is also one of the most abundant materials on the earth's crust [4]. Extraction process has been employed for the production of silica making use of quartz or sand as raw materials [3]. Smelting quartz and sand with sodium carbonate at $1300^{\circ} \mathrm{C}$ is currently used in manufacturing sodium silicate, the precursor for silica production [5].

The International Union of Pure and Applied Chemistry
(IUPAC) defined Green Chemistry as the invention, design and application of chemical products and processes to reduce or eliminate the use and generation of hazardous substances [6, 7]. Synthetic materials based upon fossil fuels and oil has pushed aside none food raw materials from agriculture and other land-based industries [8]. Much attention has been attracted to agro-industrial wastes in recent times due to its potential sources of novel green alternatives such as biotransformation for fuels and other materials [9].

Agricultural products and residues attract widespread attention for renewable energy generation and their large-scale combustion. Many agricultural products as well as their byproducts which include palm oil, sugarcane bagasse and waste 
like ashes produced from palm oil fuel, rice husk ash or wheatstraw/husk are considered potential raw materials for preparing valuable products. Silica is one of such products. Herbaceous plants cultivated by irrigation method and fertilizer application has led to higher content of inorganic species compared to wood or coal, with ash content of between 3-12 weight percent $(\mathrm{wt} \%) .[7,10,11]$ There is therefore urgent need to extract, recover, recycle and reuse inorganic species or elements. Combustion of herbaceous biomass results in the production of fly ash and bottom ash. The fly ash is mainly composed of potassium, sodium, sulfates, chlorides and phosphates while the bottom ash is rich in silica or silicates [12]. Research has shown that bottom ashes from biomass (rice husk) and biomass power station waste could be used for reforming silicate solutions by alkaline extraction, to obtain higher value end-products [13].

Currently, especially in developing countries like Nigeria, most of the waste agricultural biomass is left in the field to decompose naturally, which releases $\mathrm{CO}_{2}$ and the high global warming greenhouse gas, methane. These agricultural wastes when burnt openly, releases gaseous emissions such as CO (a poisonous gas) as well as a black carbon which also has high global warming potential [14].

Manjula et al. [15] reported the extraction of Silica from cow dung using precipitation method. Cow dung ash was mixed with sodium hydroxide to produce sodium silicate which was filtered and the residue thoroughly washed with double distilled water. The filtrate: sodium silicate was acidified with $5 \mathrm{~N} \mathrm{H}_{2} \mathrm{SO}_{4}$ to precipitate silica gel. The silica gel was washed with double distilled water to free the filtrate from alkali and oven dried at the temperature of $110^{\circ} \mathrm{C}$ yielding nano sized amorphous silica. Manjula et al [15] characterized the product using SEM, EDX and XRD.

Precipitation method has also been reported [9] for production of silica nanoparticles from coconut shell ash. After heating the coconut shell in a furnace at $700^{\circ} \mathrm{C}$ to produce coconut shell ash (CSA), $2.5 \mathrm{M} \mathrm{NaOH}$ was added and stirred with it to form sodium silicate. Upon treatment of the sodium silicate with $5 \mathrm{~N} \mathrm{H}_{2} \mathrm{SO}_{4}$, silica gel precipitated out which was washed and dried in an oven to produce amorphous silica which was later refluxed with $6 \mathrm{M} \mathrm{HCl}$ and washed to remove the alkali. The solution was treated with $2.5 \mathrm{M} \mathrm{HCl}$ and $\mathrm{H}_{2} \mathrm{SO}_{4}$ to give white precipitate which was dried to obtain silica nano particles. The silica nano particles were characterized by FTIR, XRD and SEM [9].

Citric acid leaching treatment has been reported for extraction of silica from palm ash, [7]. The heating temperature, reaction time and concentration parameters on palm ash for silica extraction by leaching process were investigated. The effect of acid concentration on palm ash showed an increase percentage of extracted silica as the concentration increases [7]. Silica in micro and nano size forms find application in industries as precursor in ceramic production, synthesis of highly active silica gel, pharmaceutical products and as semiconductors, etc. [8].

\section{Materials and Methods}

\subsection{Materials, Reagents and Equipments}

Borassus aethiopum leaves (BAL), Raphia africana fruit shells (RAS), hot air oven, weighing balance, muffle furnace, $2.5 \mathrm{~mol} / \mathrm{dm}^{3}$ sodium hydroxide solution, $2.5 \mathrm{~mol} / \mathrm{dm}^{3} \mathrm{H}_{2} \mathrm{SO}_{4}$ solution, $6 \mathrm{~mol} / \mathrm{dm}^{3} \mathrm{HCl}$ solution, $2.5 \mathrm{~mol} / \mathrm{dm}^{3} \mathrm{HCl}$ solution and concentrated $\mathrm{H}_{2} \mathrm{SO}_{4}$, Fourier transform infrared spectrophotometer (FTIR), X-ray fluorescence spectrometer (XFS), Atomic Absorption Spectrometer and Scanning electron microscope (SEM).

\subsection{Sample Collection}

BAL was harvested from a farm in Kusuv along Tyowanye - Jor Mbatyough Road in Buruku Local Government Area, Benue State, Nigeria. RAS was purchased from a market at Tyowanye, Shorov, Buruku Local Government area of Benue State, Nigeria where the fruit is marketed for commercial purpose.

\subsection{Preparation of Sample}

BAL and RAS were washed with distilled water thoroughly to remove dirt and other impurities. The washed precursors were dried in hot air oven for 2 hours at $100^{\circ} \mathrm{C}$ [9].

\subsection{Preparation of Borassus aethiopum Leaves Ash (BALA) and Raphia africana Fruit Shells Ash (RASA)}

Three portions $(20 \mathrm{~g}$ each) of dried BAL were combusted in an electric furnace with air at $650^{\circ} \mathrm{C}$ for 4 hours. The temperature was maintained throughout this process to prevent crystallization of silica to form cristobalite and tridymite. The ash was collected, labeled as BALA and analysed. A similar procedure was used for RAS to produce the ash, RASA [16]

\subsection{Extraction of Biosilica}

The BALA and RASA were separately made into fine powder using mortar and pestle. The powder (10 g each) was stirred with $2.5 \mathrm{~mol} / \mathrm{dm}^{3} \mathrm{NaOH}$ solution using $250 \mathrm{~mL}$ beaker for 4 hours at $100^{\circ} \mathrm{C}$ to produce sodium silicate solution. The solution was filtered and the residue washed with boiling water. The filtrate was stirred with $2.5 \mathrm{~mol} / \mathrm{dm}^{3}$ $\mathrm{H}_{2} \mathrm{SO}_{4}$ at $100^{\circ} \mathrm{C}$ to precipitate the silica gel. The gel was washed with deionized water to remove sulphate impurities and heated in an oven at $70^{\circ} \mathrm{C}$ for 15 hours to form amorphous silica. The amorphous silica was refluxed at $90^{\circ} \mathrm{C}$ with $6 \mathrm{M} \mathrm{HCl}$ for 6 hours and washed with distilled water to remove alkali or minerals such as $\mathrm{Al}, \mathrm{Na}$ etc. The sample was treated with $2.5 \mathrm{M} \mathrm{NaOH}$ and stirred continuously using a magnetic stirrer for 10 hours at 90 $100^{\circ} \mathrm{C}$. The formed sodium silicate was acidified with concentrated $\mathrm{H}_{2} \mathrm{SO}_{4}$ to adjust the $\mathrm{pH}$ to the range $7.5-8.5$ to form white precipitate. The white precipitate was filtered and dried in hot air oven at $110^{\circ} \mathrm{C}$ for 30 hours to obtain silica particles [8, 15, 17]. 


\subsection{Characterization of Biosilica}

The chemical bonds in extracted biosilica obtained from BASA and RASA were determined using FT-IR spectrophotometer $8400 \mathrm{~s}$ Shimadzu 4000-450 $\mathrm{cm}^{-1}$ [18] at the Joseph Sarwuan Tarka University Makurdi-Nigeria and Ahmado Bello University, Zaria-Nigeria.

The morphologies of BASA and RASA were determined using Scanning Electron Microscope while their chemical compositions were determined using X-ray fluorescence [19, 20].

BALA and RASA (5 g, each) were separately first digested with $1 \mathrm{~N} \mathrm{HCl}$ at $90^{\circ} \mathrm{C}$ and mixed properly, filtered and kept in polyethylene bottle before transferred to atomic absorption spectrophotometer for determination of their chemical composition [21].

\section{Results and Discussion}

\subsection{FTIR}

Fourier transformed infrared (FTIR) spectra for biosilica from BAL and RAS respectively are shown in figures 1 and 2, respectively. Broad bands due to the stretching vibration of the $\mathrm{H}-\mathrm{O}-\mathrm{H}$ bond from the silanol groups were observed at 3395.60 and $3388.20 \mathrm{~cm}^{-1}$. This is attributed to the adsorbed water molecules on the surface of the silanol [5, 22-24] goup. Bending modes of water molecules trapped in the matrix of silica reported by Music, S., Filipovic, V., and Sekvanic, L. [25] and Faizul C. P., Abdulah C., and Fazhul B. [5] showed vibrational bands at 1636.3 and $1640.0 \mathrm{~cm}^{-1}$. Asymmetric bending modes or vibration of siloxane (Si-O-Si) were observed at the bands: 1062.3 and $1058.6 \mathrm{~cm}^{-1}$. Bands at 957.9 and $957.9 \mathrm{~cm}^{-1}$ correspond to symmetric bond stretching modes of siloxane (Si-O-Si) while band at 797.7 and $793.7 \mathrm{~cm}^{-1}$ correspond to its bending modes [23]. Vibrational frequencies at $1871.1,1986.7,2109.7$, and $2165.6 \mathrm{~cm}^{-1}$ could be attributed to impurities or the gel's vibration mode [15].

\subsection{Scanning Electron Microscopy (SEM)}

The morphologies of biosilica from BALA and RASA at different magnifications were determined using SEM. The micrographs for BALA are shown in figures 3, 4 and 5. The micrographs for RASA are shown in figures 6,7 and 8 . The results showed that the silica particles formed aggregates of various sizes with a broad range of size distribution. This agrees with the report by Napierska, D., Thomassen, L. CJ., Lison, D., Martens, J. A., and Hoet, P. [26]. The aggregate formation or agglomeration is attributed to the hydrogen bonding between silanol groups on the surface of silica [9, 27-29].

\subsection{X-ray Fluorescence (XRF)}

Figures 9 and 10 show the XRF spectra for biosilica obtained from BALA and RASA, respectively. The spectra showed two major peaks corresponding to the presence of silicon and oxygen which confirms predominant in biosilica from the samples and other traces due to impurities. Manjula K. R, Palamsamy P. N and Sivakumar [15] and by Music, S., Filipovic, V., and Sekvanic, L. [25] reported similar results.

\subsection{Chemical Composition}

The chemical composition of the extracted biosilica obtained from BALA and RASA at $650^{\circ} \mathrm{C}$ are shown in Tables 1 and 2. The results showed that BALA contained approximately $88 \%$ silica while RASA has $70 \%$ silica. In both samples, silica was obtained as the component with highest concentration in $w t \%$ while other components were obtained in trace percentages [30].

Tables 3 and 4 report the chemical composition of raw BALA and RASA at $650^{\circ} \mathrm{C}$. The results revealed that BALA has $80 \%$ while RASA has about $67 \%$ silica. This is in agreement with the report by Faizul C. P., Abdulah C., and Fazhul B. [5, 28]. The concentration of the extracted biosilical in BALA $(87.9 \%)$ is higher than that obtained from the ash content (82\%). Similarly, for RASA, the extracted showed $70.3 \%$ silica while its ash recorded $67.7 \%$. This is in agreement with the observations of Vaibhav, V., Vijayalakshmi,, U., and Roopan, S. M. [31] nd Khushbu G. P, Rakshith R. S, and Nirendra M. M. [32] as the major mineral component found in rice husk. The other components where found in very trace percentages.

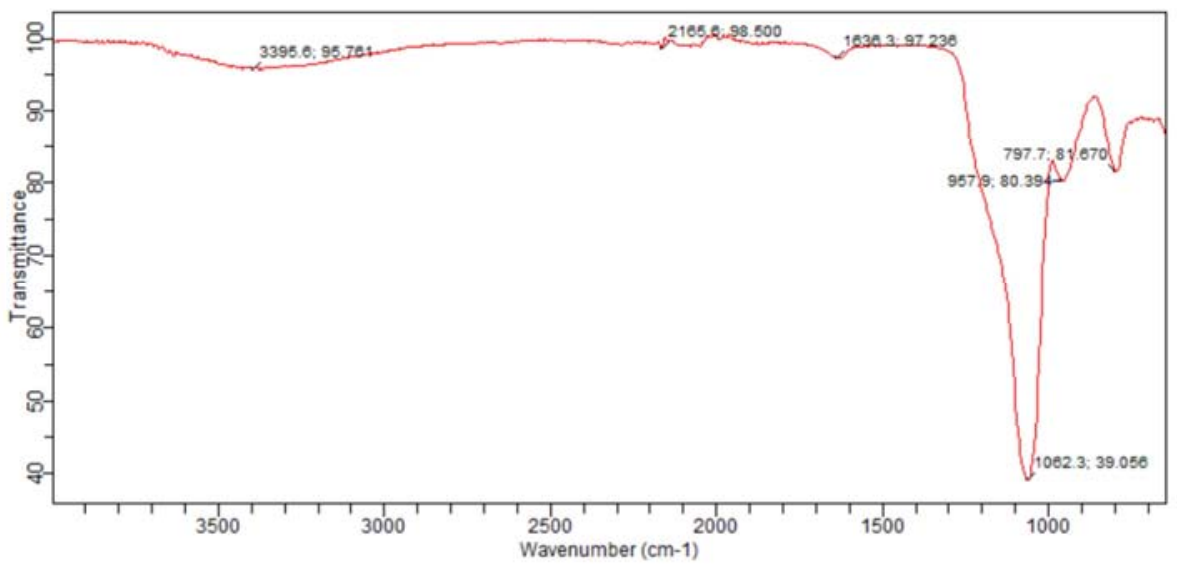

Figure 1. FTIR Spectra of Biosilica from Borassus aethiopum Leaves Ash. 


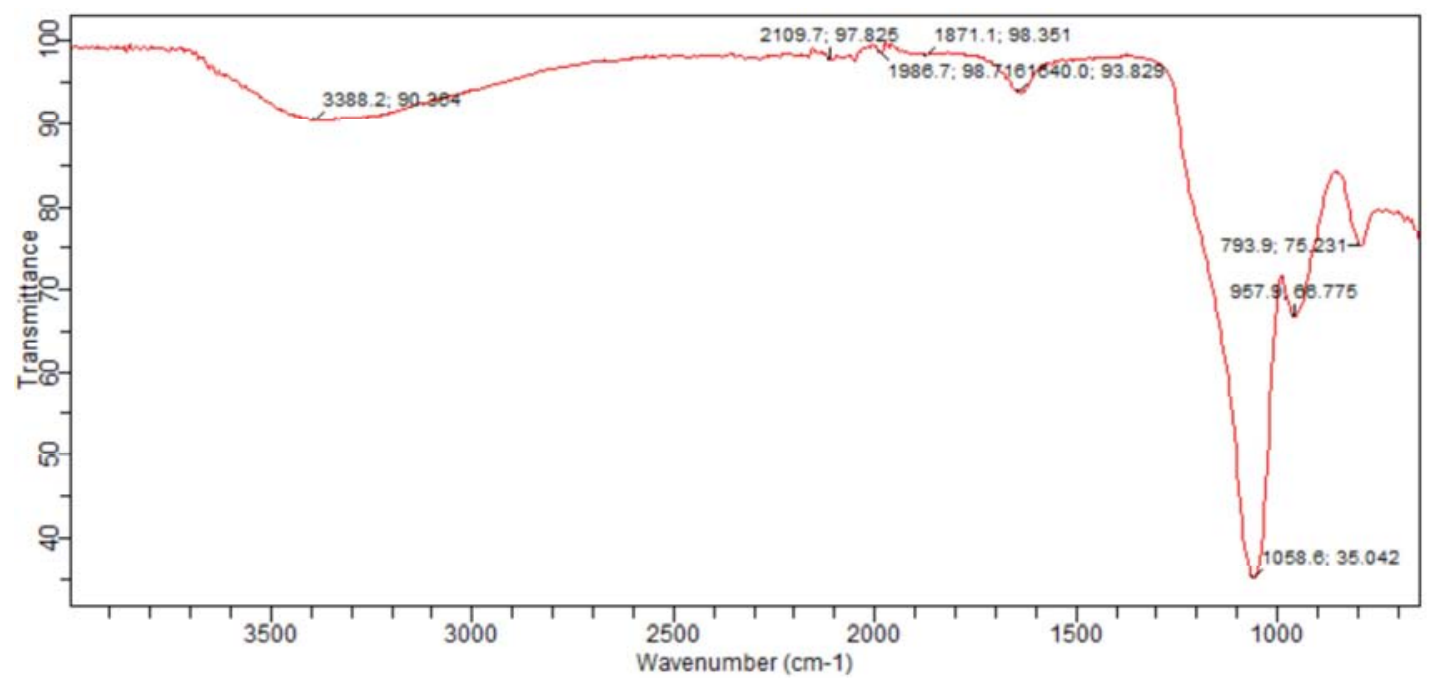

Figure 2. FTIR Spectra of Biosilica from Raphia africana Fruit Shells Ash.

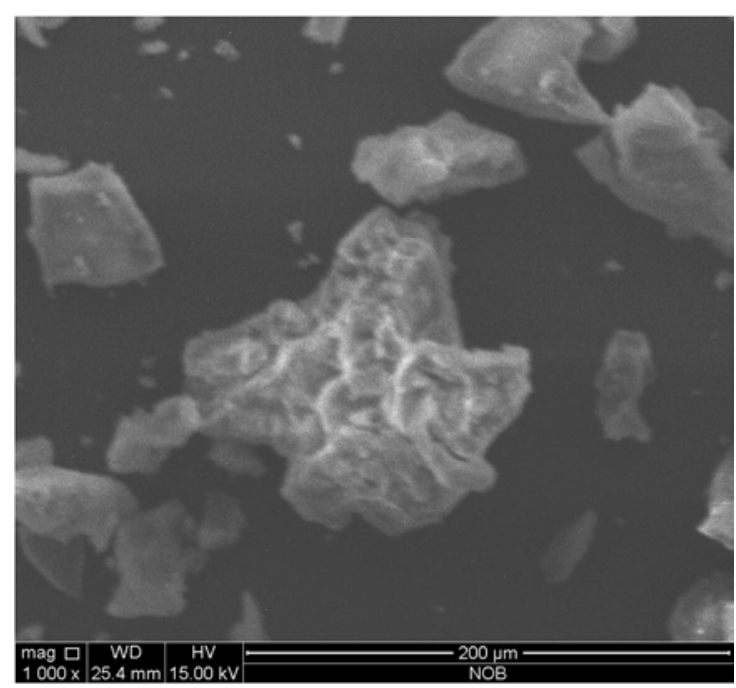

Figure 3. Scanning Electron Microscpe Image of Biosilica Extracted from Borassus aethiopum Leaves Ash at mag. 1000x.

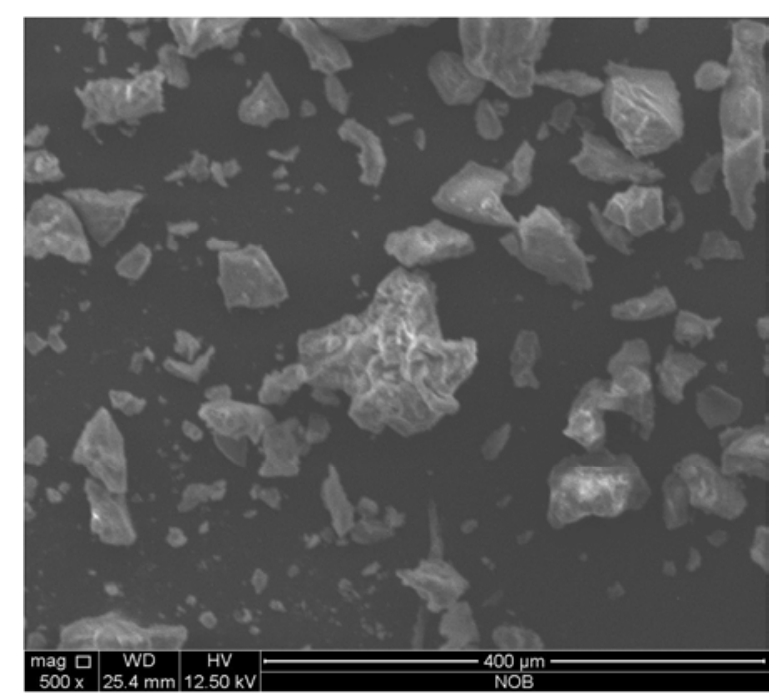

Figure 4. Scanning Electron Microscope Image of Biosilica Extracted from Borassus aethiopum Leaves Ash at mag. 500x.

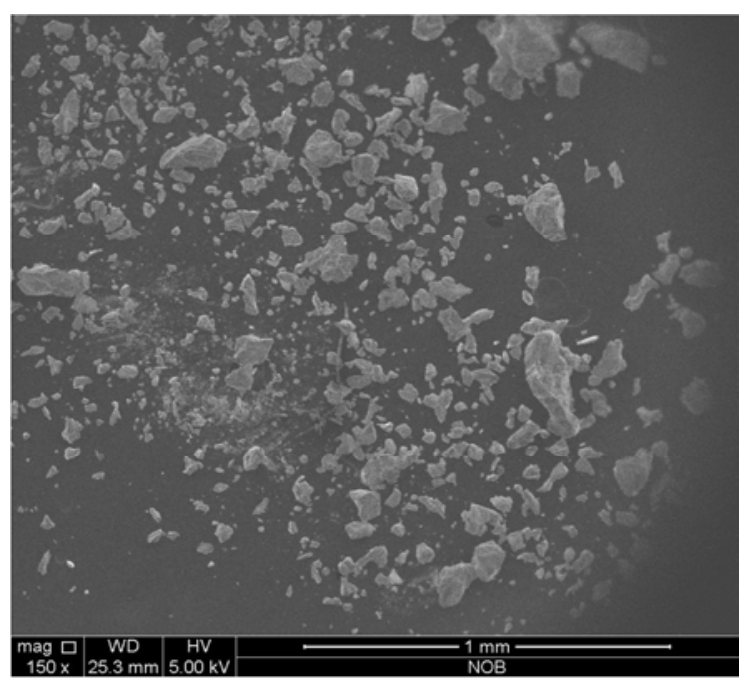

Figure 5. Scanning Electron Microscope Image of Biosilica Extracted from Borassus aethiopum Leaves Ash at mag. 150x.

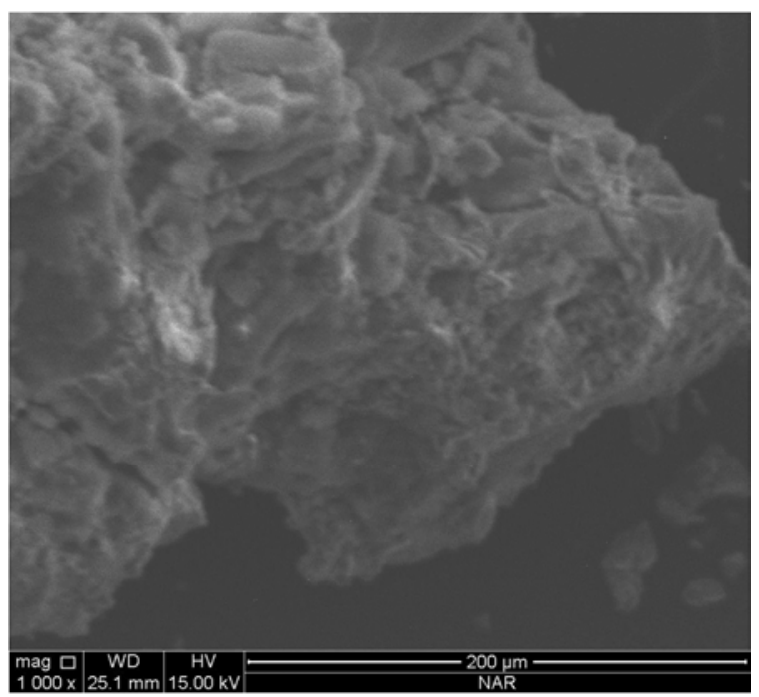

Figure 6. Scanning Electron Microscope Image of Biosilica Extracted from Raphia africana Fruit Shells Ash at mag. 1000x. 


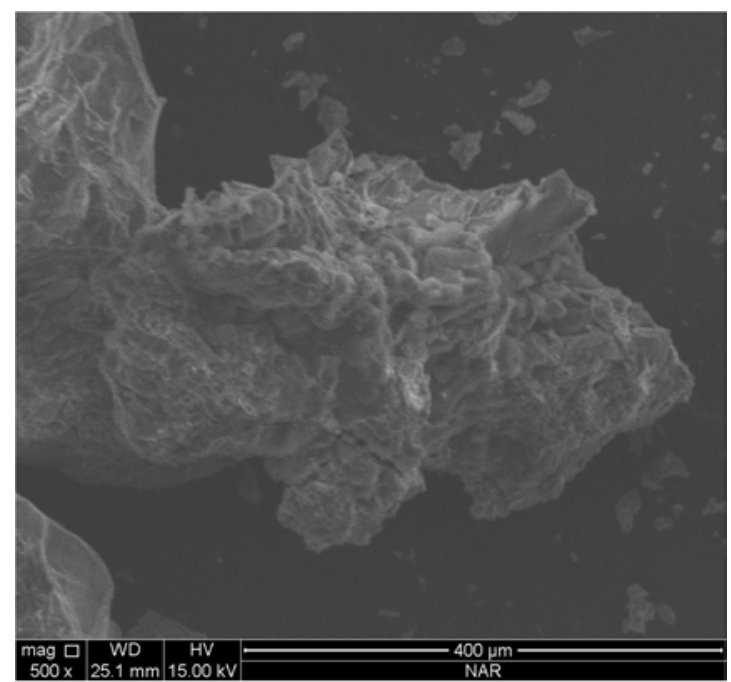

Figure 7. Scanning Electron Microscope Image of Biosilica Extracted from Raphia africana Fruit Shells Ash at mag. 500x.

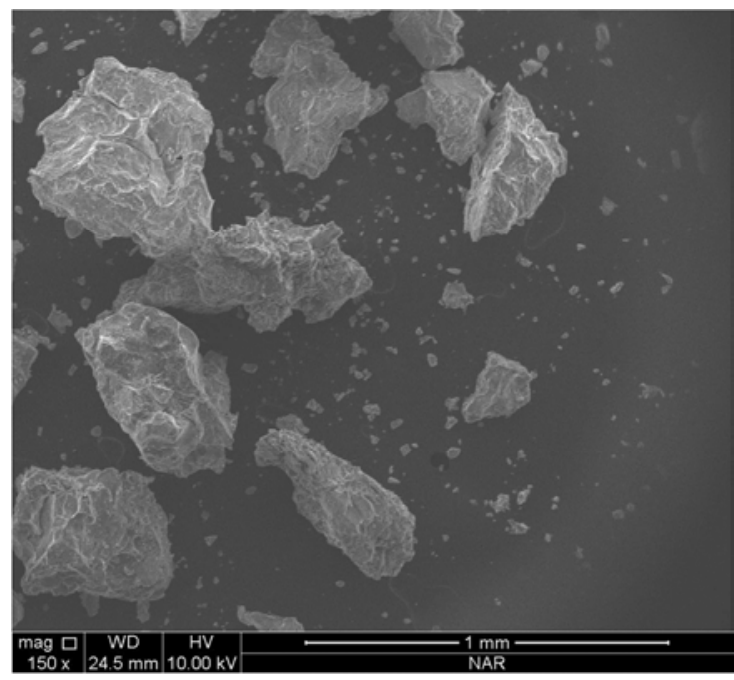

Figure 8. Scanning Electron Microscope Image of Biosilica Extracted from Raphia africana Fruits Shells Ash at mag. 150x.

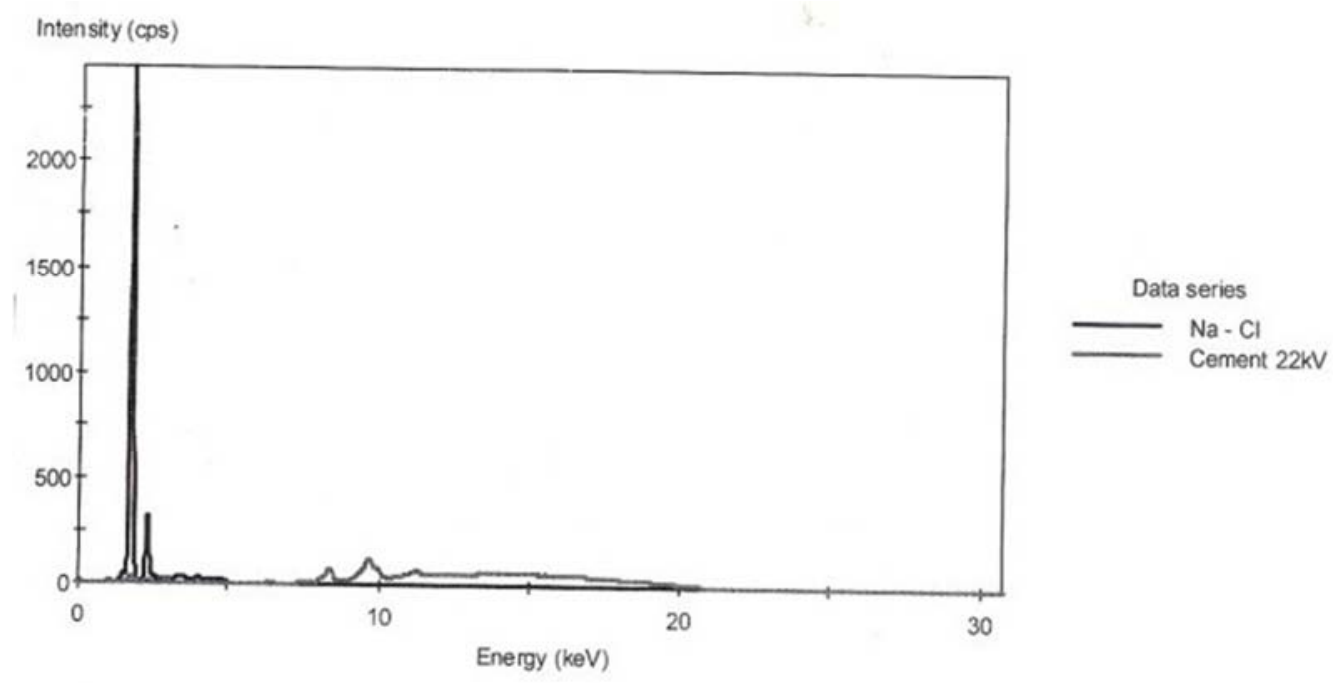

Figure 9. X-ray Fluorescence Spectra of Biosilica from Borassus aethiopum Leaves As.

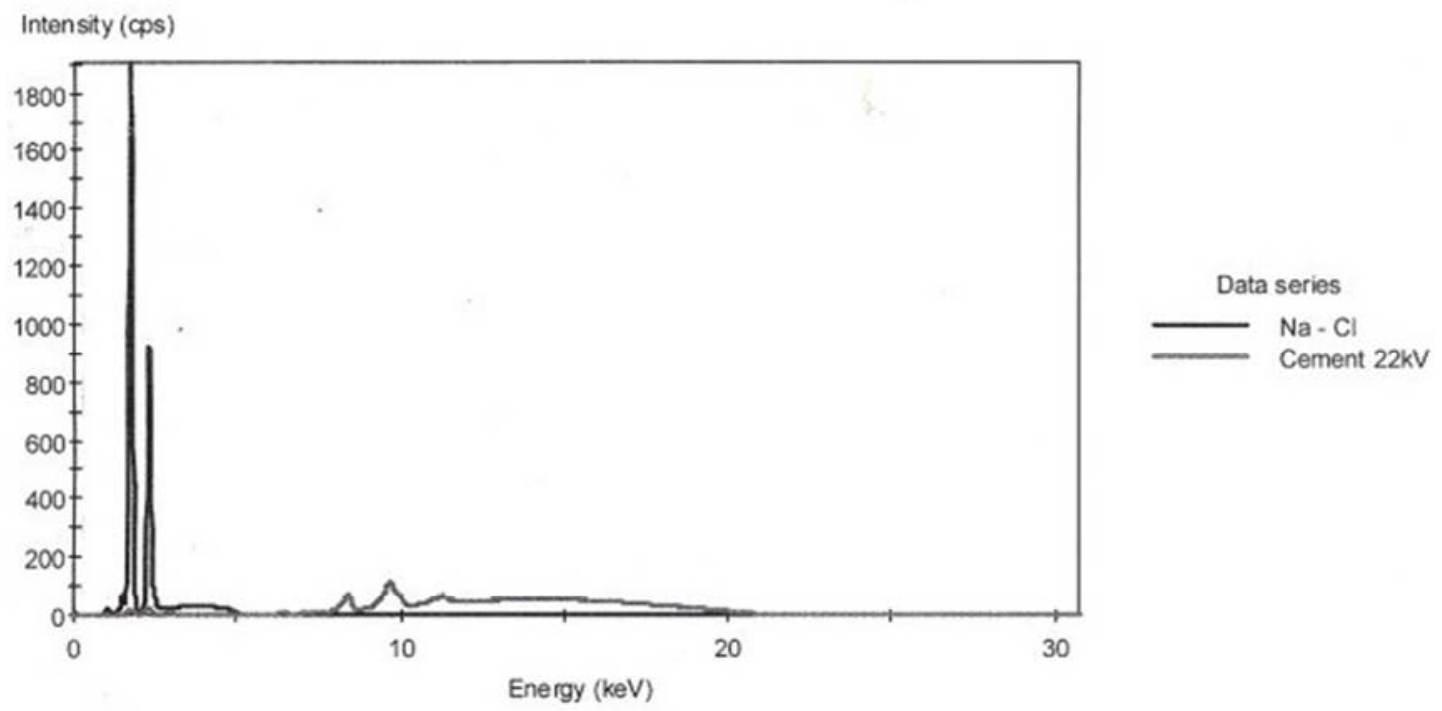

Figure 10. X-Ray Fluorescence Spectra of Biosilica from Raphia africana Fruit Shells Ash. 
Table 1. Composition of Extracted Biosilica from BASA at $650^{\circ} \mathrm{C}$.

\begin{tabular}{ll}
\hline Elements & Concentration (wt\%) \\
\hline $\mathrm{Na}_{2} \mathrm{O}$ & 3.483 \\
$\mathrm{MgO}$ & 0.047 \\
$\mathrm{Al}_{2} \mathrm{O}_{2}$ & 1.256 \\
$\mathrm{SiO}_{2}$ & 87.961 \\
$\mathrm{P}_{2} \mathrm{O}_{2}$ & 0.100 \\
$\mathrm{SO}_{2}$ & 7.038 \\
$\mathrm{Cl}$ & 0.056 \\
$\mathrm{~K}_{2} \mathrm{O}$ & 0.024 \\
$\mathrm{CaO}$ & 0.005 \\
$\mathrm{TiO}_{2}$ & 0.003 \\
$\mathrm{Cr}_{2} \mathrm{O}_{3}$ & 0.002 \\
$\mathrm{MnO}_{2}$ & 0.002 \\
$\mathrm{Fe}_{2} \mathrm{O}_{2}$ & 0.022 \\
$\mathrm{ZnO}$ & 0.000 \\
$\mathrm{SrO}$ & 0.000 \\
\hline
\end{tabular}

Table 2. Composition of Extracted Biosilica from RASA at $650^{\circ} \mathrm{C}$.

\begin{tabular}{ll}
\hline Elements & Concentration (wt\%) \\
\hline $\mathrm{Na}_{2} \mathrm{O}$ & 7.795 \\
$\mathrm{MgO}$ & 0.073 \\
$\mathrm{Al}_{2} \mathrm{O}_{2}$ & 1.900 \\
$\mathrm{SiO}_{2}$ & 70.316 \\
$\mathrm{P}_{2} \mathrm{O}_{2}$ & 0.093 \\
$\mathrm{SO}_{2}$ & 19.720 \\
$\mathrm{Cl}$ & 0.031 \\
$\mathrm{~K}_{2} \mathrm{O}$ & 0.027 \\
$\mathrm{CaO}$ & 0.007 \\
$\mathrm{TiO}_{2}$ & 0.005 \\
$\mathrm{Cr}_{2} \mathrm{O}_{3}$ & 0.002 \\
$\mathrm{MnO}_{2}$ & 0.002 \\
$\mathrm{Fe}_{2} \mathrm{O}_{2}$ & 0.027 \\
$\mathrm{ZnO}_{\mathrm{SrO}}$ & 0.000 \\
\hline
\end{tabular}

Table 3. Composition of Biosilica from BASA (Raw) at $650^{\circ} \mathrm{C}$.

\begin{tabular}{ll}
\hline Elements & Concentration (wt\%) \\
\hline $\mathrm{Na}_{2} \mathrm{O}$ & 0.653 \\
$\mathrm{MgO}$ & 0.169 \\
$\mathrm{Al}_{2} \mathrm{O}_{2}$ & 4.730 \\
$\mathrm{SiO}_{2}$ & 82.900 \\
$\mathrm{P}_{2} \mathrm{O}_{2}$ & 0.308 \\
$\mathrm{~K}_{2} \mathrm{O}$ & 2.339 \\
$\mathrm{CaO}$ & 3.605 \\
$\mathrm{TiO}$ & 0.243 \\
$\mathrm{MnO}_{2}$ & 0.021 \\
$\mathrm{Fe}_{2} \mathrm{O}_{2}$ & 0.021 \\
$\mathrm{ZnO}$ & 0.018 \\
\hline
\end{tabular}

Table 4. Composition of Biosilica from RASA (Raw) at $650^{\circ} \mathrm{C}$.

\begin{tabular}{ll}
\hline Elements & Concentration (wt\%) \\
\hline $\mathrm{Na} \mathrm{N}_{2} \mathrm{O}$ & 0.181 \\
$\mathrm{MgO}$ & 0.827 \\
$\mathrm{Al}_{2} \mathrm{O}_{2}$ & 5.407 \\
$\mathrm{SiO}_{2}$ & 67.706 \\
$\mathrm{P}_{2} \mathrm{O}_{2}$ & 0.405 \\
$\mathrm{~K}_{2} \mathrm{O}$ & 3.970 \\
$\mathrm{CaO}$ & 2.330 \\
$\mathrm{TiO}$ & 0.562 \\
$\mathrm{MnO}_{2}$ & 0.164 \\
$\mathrm{Fe}_{2} \mathrm{O}_{2}$ & 0.030 \\
$\mathrm{ZnO}$ & 0.004 \\
\hline
\end{tabular}

\section{Conclusion}

The study revealed that $70-90 \%$ silica can be extracted from BALA and RASA by precipitation method. These common wastes burnt at controlled temperature produced large amount of ashes. These ashes can be subjected to chemical treatment to extract silica particles. Particles obtained from precipitation method contain mainly silica and $\mathrm{OH}$ groups. Based on FTIR and SEM analysis they present a trend toward a spherical morphology $[5,26]$. AAS results showed that the ashes are highly rich in silica due to low level of impurities. The high silica content can be used to prepare silica compounds and can minimize the environmental impact of BAL and RAS as such, converting waste to wealth and reducing the concentration of greenhouse gases like $\mathrm{CO}_{2}$ which are released when plant wastes are left to decompose on their own.

\section{References}

[1] Agamuthu, P. (2009) Challenges and opportunities in Agrowaste Management: An Asian perspective. Inaugural meeting of First Regional 3R Forum in Asia 11-12 Nov. Tokyo, Japan.

[2] Obi, F. O., Ugwuishiwu, B. O., and Nwakaire, J. N. (2016). Agricultural Waste Concept, Generation, Utilization and Management. Nigerian Journal of Technology (NIJOTECH), 35 (4): 957-964

[3] Kalapathy, U., A. Proctor \& J. Shultz, (2000). A Simple Method for Production of Pure Silica from Rice Hull Ash, Bioresource Technology, 73: 257-262.

[4] Permatasari, N., Sucahya, T. N., and Dani Nandiyanto, A. B. (2017) "Review: Agricultural Wastes as a Source of Silica Material," Indonesian. Journal Science. And Technology., 1 (1).

[5] Faizul C. P, Abdulah C. and Fazhul B. (2013). Extraction of Silica form Palm Ashvia Citric acid Leaching Treatment. AENSI Journals: Advances in Enviromental Biology, 7 (12): 3690-3695.

[6] Tundo, P., Anastas, P., Black, D. S., Breen, J., Collins, T., Memoli, S., Miyamoto, J., Polyakoff, M., and Tumas, W. (2000). Synthetic Pathways and Processes in Green Chemistry. Introductory Overview. Pure Applied Chemistry. 72 (7): 1207-1228.

[7] Shaikh, I. R. and Shaikh A. A. (2013). Utilization of Wheat Husk Ash as Silica source for the Synthesis of MCM-41 type Mesoporous Silicate. A Sustainable Approach towards Valorization of the Agricultural Waste Stream. Research Journal of Chemical Science., 3 (11): 66-72.

[8] Melvyn F. A (2004). An Overview of Biomaterial. Biomass and Agricultural Sustainable Markets and Policies. Organization for Economic Cooperation and Development, 77-78.

[9] Sivasubramanian S and Kurchalapati Sravanthi (2015). Synthesis and Characterization of Silica Nanoparticles from Coconut Shells. International Journal of Pharma and Bio Science, 6 (1): 530-536. 
[10] Dayton D. C., Jenkins B. M., Turn S. Q., Bakker R. R., Williams R. B., Belle-Oudry D. and Hill L. M., (1999). Release of Inorganic Constituents from Leached Biomass during Thermal Conversion, Energy Fuels, 13, 860-870.

[11] Sander M. L. and Andren O., (1997). Ash from Cereal and Rape Straw used for Heat Production: Liming Effect and Contents of Plant Nutrients and Heavy Metals, Water Air Soil Pollut., 93: 93-108.

[12] Miles T. R., Baxter L. L., Bryers R. W., Jenkins B. M. and Oden L. L. (1996). Boiler deposits from firing biomass fuels, Biomass and Bioenergy, 10: 125-138.

[13] Shelke V. R., Bhagade S. S. and Mandavgane S. A. (2010), Mesoporous Silica from Rice Husk Ash, Bull. Chem. Reaction. Engg. \& Cata., 5 (2): 63-67.

[14] UNEP (2013). International Environmental Technology Centre, Policy brief on waste Agricultural Biomass.

[15] Manjula K. R, Palamsamy P. N and Sivakumar (2014): Synthesis and Characterization of Amorphous Nano Silica from Biomass Ash. International Journal of Advanced Technology in Engineering and Science, 2 (10): 72-75.

[16] Kien-Woh K, Rozita Y, A. R. Abdul Aziz and Abdulallah (2014). Characterisation of biosilicasynthesised from cogon grass. Powder Technology. Journal homepage www.elseveir.com/locate/powtech: 206-207.

[17] Khushboo S, Niherika S, Vijay, D. and Ashu R (2013). Pure Silica Extraction from Perlite. Its Characterization and Affecting Factors. International Journal of Innovative Research in Science, Engineering and Technology, 2 (7): 2936-2941.

[18] David H. (2000), Modern Analytical Chemistry. $1^{\text {st }}$ Edition. Mcgrew Hill Higher Education, USA: 393-394.

[19] Francis, R. and Annick, R. (2000). Chemical Analysis: Modern Instrumentation Methods and Techniques, $4^{\text {th }}$ Edition, John Willey ans Sons Ltd. Chichester, 170-177.

[20] Omolola, K. M. and Onoja, A. D. (2009). Elemental Analysis of Rice Hursk Ash using X-ray Fluorescence Technique. International Journal of Physical Sciences, 4 (4): 190-191.

[21] Omoniyi, T. E. and Olorunnisola, A. O. (2014), Experimental Characterization of Bagasse Biomass Material for Energy Production. IJET International Journal of Engineering and Technology, 4 (10): 582-589.

[22] Dongmin An, Yupeng Guo, Yanchao Zhu and Zichen Wang, (2010). A Green Route to Preparation of Silica Powders with
Rice Husk Ash and Waste Gas, Chemical Engineering Journal, 162: $509-514$

[23] Mahwish S, Masooma R, Hassan J. N, Sidra J and Amma A (2014). Synthesis of Precipitated Silica from Corn Cob using Organic Acid. Science Internationa l (Lahore), 27 (1): 265267.

[24] Aznizam, A. B., Azman, M., and Mya, F. (2006). The Effect of Oil Extraction of the Oil Palm Empty Fruit Bunch on the Processability, Impact and Flexural Properties of PVC UComposite, International Journal of Polymeric Materials 55 (9).

[25] Music S; Filipovic V and L. Sekvanic (2011). Preparation of Amorphous silica particles and their properties, Brazilian Journal of Chemical Engineering, 28 (1): 92-93.

[26] Napierska D., Thomassen, L. CJ., Lison, D., Martens, J. A., and Hoet, P. H. (2010). Review: The Nanosilica Hazard: Another Variable Entity. Particle and Fibre Toxicology, 7:39. $\mathrm{http}: / / \mathrm{www}$.particleandfibretoxicology.com/content/7/1/39

[27] Poulomi, Sarkar., SK., Abdul., M., Argha, D., Subhassis, R., and Sudip Kumar, D. (2017) . Experimental Investigation of Photocatalytic and Photovoltaic Activity of Titania/rice Husk Crystalline Nano silica Hybrid Composite. Solar Energy Materials and Solar Cells. 172: 93-98.

[28] Patcharin W, Wisaroot P and Akhapon M (2009). Characterization for Post Treatment of Bagasse Ash from Silica Extraction. World Academy of Science Engineering and Technology: International Journal of Chemical and Molecular Engineering, 3 (8): 398-400.

[29] Dominic C. D, Begum P. M S, Joseph R, Joseph D, Kumar P and Ayswarya E. P (2013). Synthesis, Characterization and Appilcation of Rice Husk Nanosilica in Natural Rubber. International Journal of Science, Environment and Technology, 2 (5): 1027-1035.

[30] Mahanraj K, S. Kannan, S. B., and Sivakumar, G. (2012). Preparation and Characterization of $\mathrm{NanoSiO}_{2}$ from Corn Cob Ash by Precipitation Method. Optoelectronic and Advanced Materials-Rapid Communication 6: 394-397.

[31] Vaibhav, V., Vijayalakshmi, U., and Roopan, S. M. (2014) Agricultural waste as a source for the production of silica nanoparticles, Spectrochimica Acta Part A: Molecular and Biomolecular Spectroscopy, 139: 515-520.

[32] Khushbu G. Patel, Rakshith R. Shettigar, and Nirendra M. Misra (2017) Recent Advance in Silica Production Technologies from Agricultural Waste Stream- Review. Journal of Advanced Agricultural Technologies, 4 (3): 274-279. 